\title{
THE AGRICULTURAL SUITABILITY OF CASHEW NUT SUBSTRATE ON THE GROWTH AND YIELD OF SORGHUM BICOLOR L. (SORGHUM) AND ARACHIS HYPOGAEA L. (PEANUT) ACCORDING TO THE SAMPLING DISTANCE (CASAMANCE / SENEGAL)
}

\author{
Seydou NDIAYE ${ }^{1 *}$, Mohamed Mahamoud CHARAHABIL ${ }^{1}$, Malainy DIATTA ${ }^{2}$ and Antoine SAMBOU ${ }^{1}$ \\ ${ }^{1}$ Assane Seck University of Ziguinchor, Agroforestry and Ecology Laboratory ,BP: 523 Ziguinchor, Senegal \\ ${ }^{2}$ Senegalese Agricultural Research Institute, National Forest Research Centre,Forest Park Hann Bp: 2312. Dakar, \\ Senegal
}

https://doi.org/10.35410/IJAEB.2020.5475

\begin{abstract}
The issue of cashew tree allelopathy and in particular the association with annual crops often comes up in the agronomy debate. The aim of this study is to test the agricultural suitability of cashew nut substrate on sorghum and groundnut crops. For this purpose, three types of substrates were sampled at a distance from the crown of the cashew tree (R/2), at the edge of the crown (R) and at a distance equivalent to twice the crown radius $(2 \mathrm{R})$. These substrates are then placed in trays for the cultivation of these two species under semi-controlled conditions. The experiment was carried out in a site completely exposed to the sun and isolated from the trees in order to avoid shading and competition with soil nutrients. A total randomized experimental design consisting of three treatments (three types of substrate) in 5 replicates was used. Results showed that the total biomass production of sorghum on the R/2 substrate was twice as high as that obtained on $\mathrm{R}$ and $2 \mathrm{R}$. It is estimated at $252 \mathrm{~g}$ under $\mathrm{R} / 2,135 \mathrm{~g}$ for $\mathrm{R}$ and $138 \mathrm{~g}$ under $2 \mathrm{R}$. As for sorghum, total groundnut biomass (leaves, roots, pods and stems) total biomass is higher on $\mathrm{R}$ $(331 \mathrm{~g})$ and $\mathrm{R} / 2(294 \mathrm{~g})$ substrates compared to $2 \mathrm{R}(257 \mathrm{~g})$ with a significant difference ( $\mathrm{p}=$ 0.0129). Most of the variables of the crops studied were more important on under cover than off cover. These results would indicate that if allelopathy is present, it would not be related to the substrate under the tree. A field experiment allowing the introduction of other parameters, such as the shading effect, would allow a better understanding of the conditions under which crops are associated with cashew nuts. This would be an alternative in improving crop yields and would also contribute to a better security for producers.
\end{abstract}

Keywords: Cashew nut, Annual crops, Soil sampling distance, Casamance.

\section{INTRODUCTION}

In Senegal, Anacardium occidentale L. parks are more common in Casamance, where they occupy $70 \%$ of the plateau land in the Sédhiou region [1]. Some annual crops such as (Arachis hypogaea L., Vigna unguiculata (L.) Walp., Ipomoea batatas (L.) Lam, Zea mays L. etc.) are associated in these parks [2]. In these classical traditional production systems, the associated crops, located under the tree canopy, benefit from the nutrients resulting from the decomposition 
and mineralization of the tree's organic matter [3]. This association allows agricultural production to be intensified and diversifies the producers' sources of income. However, the almost bare herbaceous cover under the cashew tree crown leads some producers to believe that the cashew tree is an allelopathic species with a negative influence on crops. However, allelopathy is defined by some authors as direct or indirect biochemical interactions, positive or negative, based on allelochemical substances involved in interspecific communication, as distinct from pheromones involved in intraspecific communication. These are most often interactions between a plant species and another species (including microorganisms), usually by means of secondary metabolites such as phenolic acids, flavonoids, trapenoids and alkaloids [4,5]. According to Waller [6] and Siqueira [7], these secondary compounds were first characterized by their protective role against pests (insects, bacteria, fungi, algae, etc.), but they can also affect the growth of other plants.

In order to test this hypothesis, an experiment was conducted for the first time in a real environment during the rainy season, where market garden crops (Tomato, okra and chilli) were grown under and out of the cashew tree cover. This was not successful because of the large amounts of rain that fell on the latter but also the crops suffered numerous attacks. Based on this finding, the study was repeated in a semi-controlled environment to see if the soils under the cashew tree are favourable for the growth and development of annual crops such as groundnut and sorghum.

In Senegal, cashew tree cultivation is developing at a very high rate. Between 1986 and 2017, the area under cashew tree cultivation increased from $910.55 \mathrm{~km} 2$ to $1908.5 \mathrm{~km} 2$ [8]. This expansion is at the expense of agricultural land and forest areas.

Given its socioeconomic importance in Senegal and more particularly in Casamance, it is necessary to study the interaction of this species with annual crops for a better valorisation of the cashew cashew nut parks. It is in this context that the present study aims to test the agricultural suitability of cashew nut substrate on crop growth and yield.

\section{MATERIALS AND METHODS}

\subsection{Experimental site}

The trial was conducted on the farm of the agroforestry department of the Assane Seck University of Ziguinchor located at $12^{\circ} 33$ North latitude and $16^{\circ} 16$ West longitude (Figure 1). This farm is located south of the town of Ziguinchor. The region of Ziguinchor covers an area of $7,339 \mathrm{~km}^{2}$ or $3.73 \%$ of the national territory and is bordered to the north by the Republic of The Gambia, to the south by the Republic of Guinea Bissau, to the east by the regions of Kolda and Sédhiou, and to the west by the Atlantic Ocean [9]. 


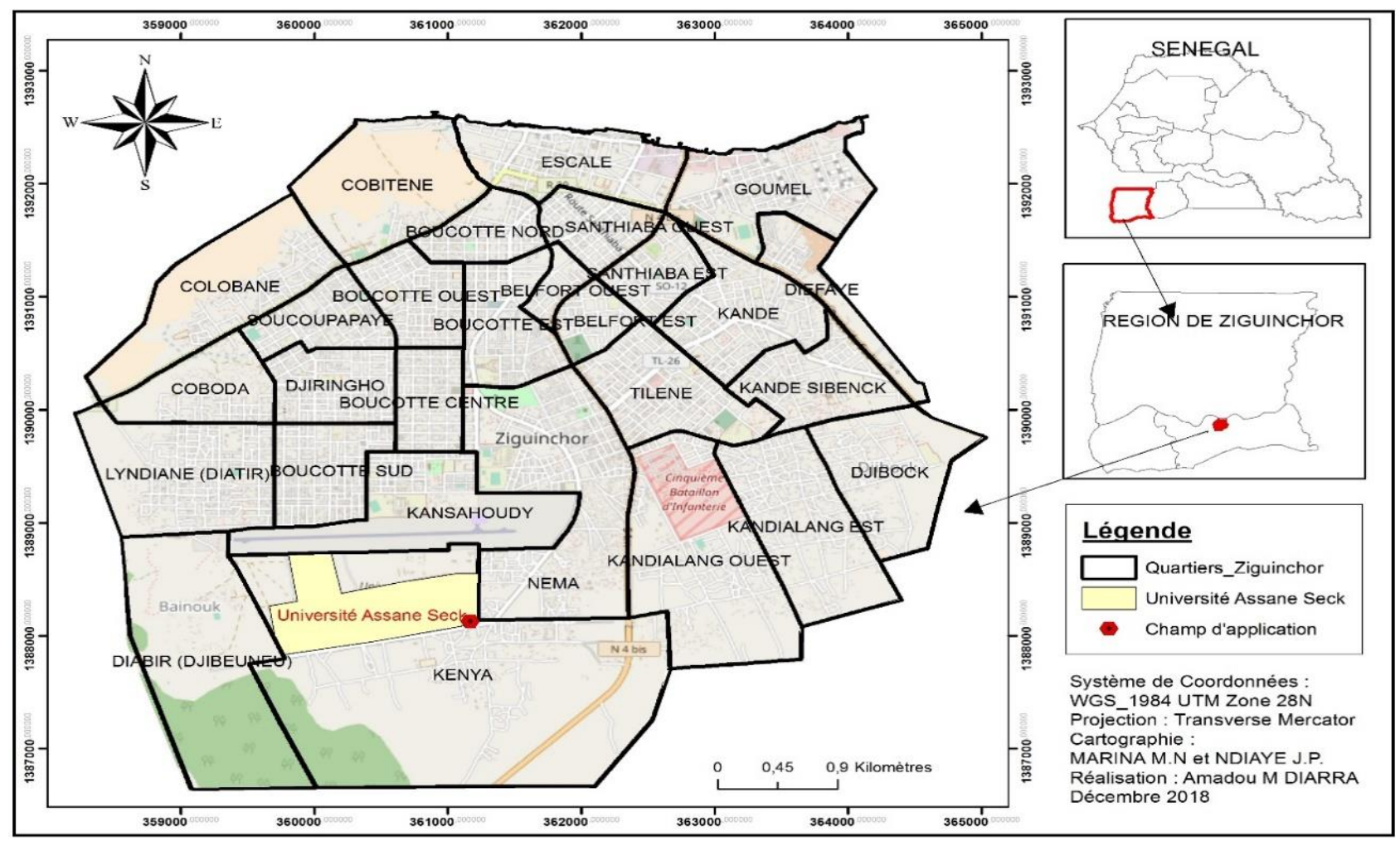

Figure 1: Location map of the experimental site

\subsection{Plant material used}

Two cultures were tested on the different substrates. These were Arachis hypogaea L. (peanut) (Figure 2a) and Sorghum bicolor L. (sorghum) (Figure 2b). The characteristics of these two crops are recorded in Table 1.

Table 1: Characteristics of the cultures tested on the different substrates

\begin{tabular}{|llll|}
\hline Scientific Names & Varieties & Origin & Cycle (Days) \\
\hline Arachis hypogaea L. & GH119-20 & Georgie (USA) & 120 \\
\hline Sorghum bicolor L. & CE180-33 & Senegal & 90 \\
\hline
\end{tabular}



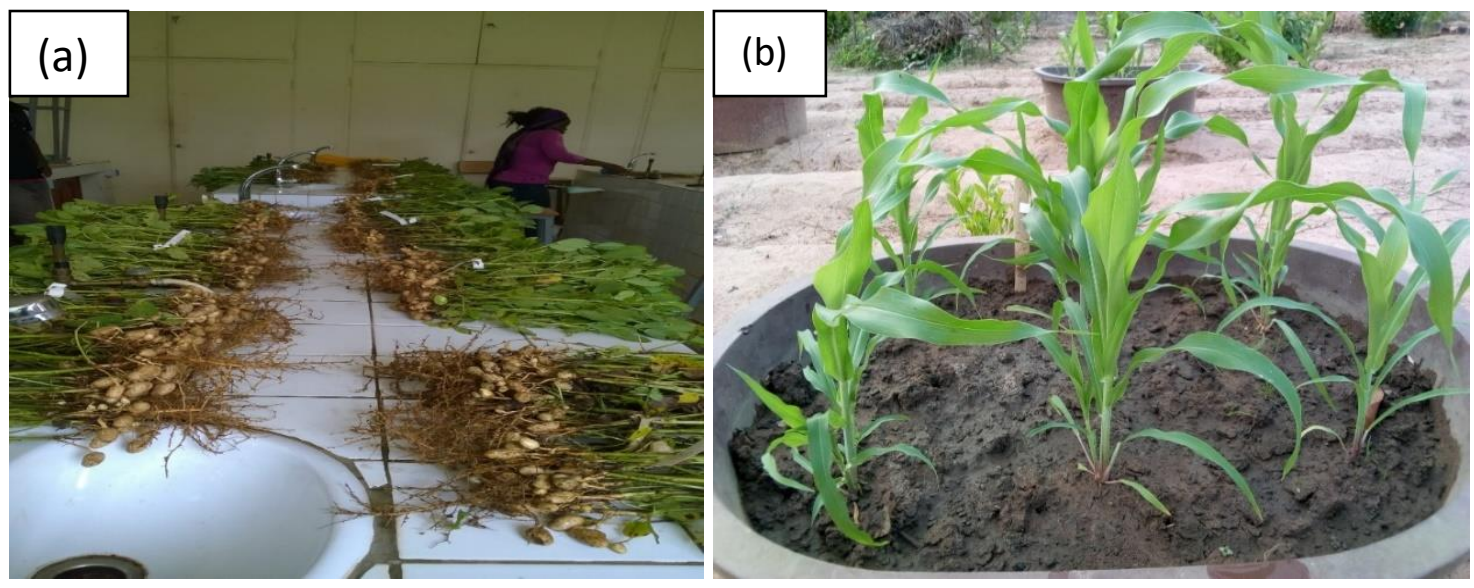

Figure 2: Annual crops tested: Peanuts (a) and Sorghum (b)

\subsection{Methods}

\subsubsection{Substrate characterization}

Soil sampling and analysis methods were used to characterize the different types of substrates used. Substrate types were collected at three levels in relation to the cashew nut crown $(R / 2, R$ and $2 \mathrm{R}$ where $\mathrm{R}$ is the radius of the cashew nut crown) in all four directions (East-West-NorthSouth). A total of 12 samples were taken, four of which were taken from each level at a depth of $30 \mathrm{~cm}$. Three composite samples were formed. The analysis of soil samples was carried out at the "Soil-Plant-Water" laboratory of the National Centre for Agronomic Research in Bambey (CNRA/Bambey). The physico-chemical parameters analysed are total nitrogen (Ntotal), organic carbon (CO), assimilable phosphorus (Passimilable), organic matter (OM), $\mathrm{pH}$, exchangeable bases $(\mathrm{Ca} 2+, \mathrm{Mg} 2+$ and $\mathrm{K}+)$ and granulometry (clay-sand-limon fraction).

The $\mathrm{pH}$ of the water is determined by the dose of $1 / 2.5$. Assimilable phosphorus is determined by the modified Bray method [10], organic carbon by the modified Walkley-Black method, total nitrogen by the modified Kjeldhal method [11] and the organic matter has been oxidised by a mixture of potassium dichromate and concentrated sulphuric acid. The excess dichromate was titrated with Mohr salt. Particle size was carried out on the basis of $20 \mathrm{~g}$ of ground soil in $25 \mathrm{ml}$ of water. Fractionation of the different particles was performed using the particle size fractionation method used by Saharta [12]-[13].

\subsubsection{Experimental design}

In order to evaluate the growth and yield parameters of two annual crops (sorghum and groundnut) on the different substrates, a completely randomized experimental design was used with four replicates and only one factor studied: the sampling distance (SD) with three levels $(\mathrm{R} / 2,1 * \mathrm{R}$ and $2 * \mathrm{R}$, where $\mathrm{R}$ was the crown radius of the tree under consideration). The 
experimental units are rings $80 \mathrm{~cm}$ long and $50 \mathrm{~cm}$ wide. For Trial 1 (groundnut), 135 bunches were made up of 09 bunches/ring, equidistant by $15 \mathrm{~cm}$. Trial 2 (sorghum) required 90 bunches due to 06 bunches/ring. In total, individuals were followed through to the production stage (Figure 3).

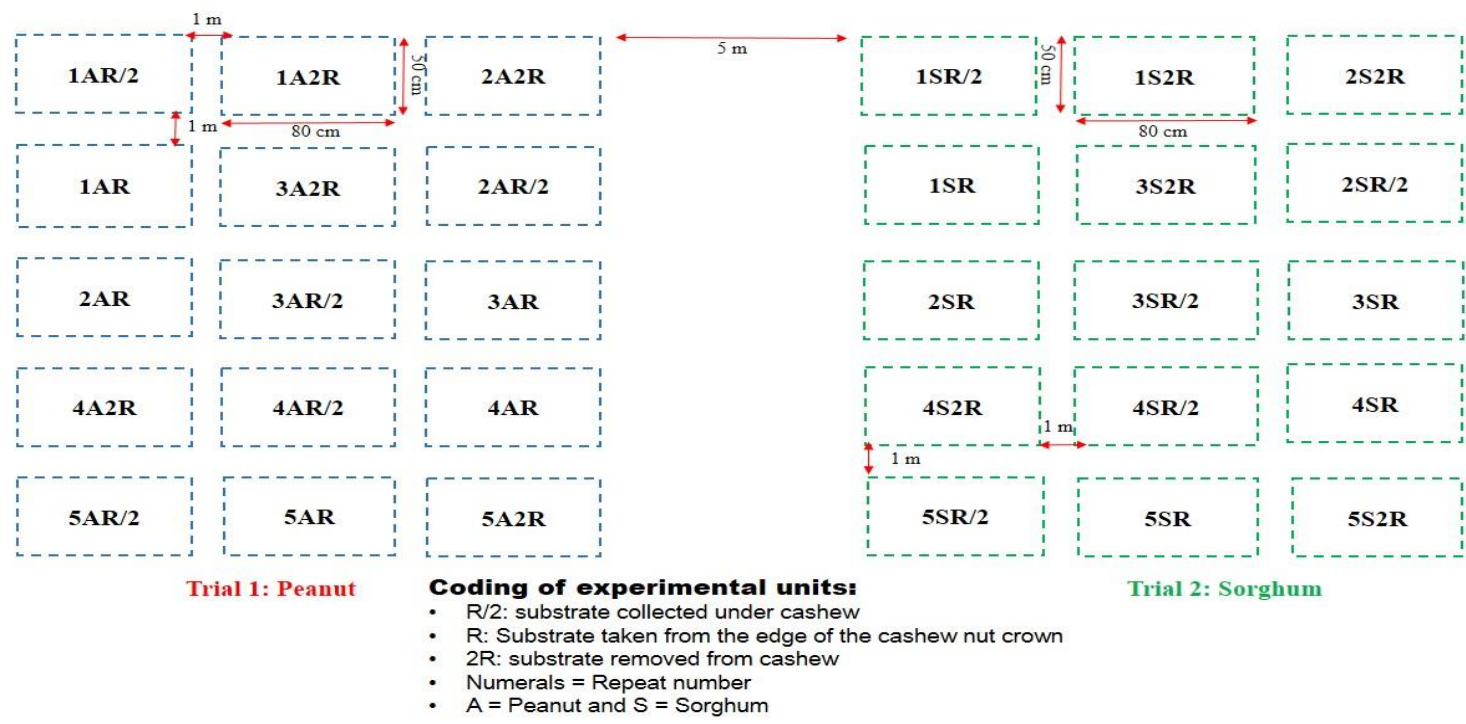

Figure 3: Experimental design

\subsubsection{Conduct of the trial}

The experiment was carried out in a site completely exposed to the sun and isolated from the trees to avoid shading and competition with soil nutrients.

Planting was carried out on 24 May 2018 for sorghum and 30 May 2018 for groundnut. The sowing density is two seeds per poquet. Measurements of growth parameters were made every 15 days after sowing (JAS). Marriage was done one week after germination (SAG) due to one plant / pots.

\subsubsection{Parameters evaluated on sorghum and peanut}

The parameters evaluated are:

For peanuts the number of stem branching, pod production, above-ground biomass (pods + tops) and below-ground biomass (roots) the ratio of total biomass and pod production but also the ratio of total biomass and mature seeds.

For sorghum, the height, diameter at collar, above-ground biomass (panicle + stems), underground biomass (roots) were evaluated.

After harvest, all crops (groundnut and sorghum) were sun-dried for 72 hours before measurement with a precision scale. 


\subsubsection{Data processing}

The data were processed using software R.3.4.2. The Shapiro test was applied to all the variables studied in order to verify the conditions of normality of the data. Thus, for the comparison of means, parametric (for variables with $p$-value $<0.05$ ) and non-parametric (p-value $>0.05$ ) tests were used. Analysis of variance (ANOVA) was used to show the effect of a factor. The Newman Keuls test at the threshold $\alpha=0.05$ was used to compare the means and show the differences between the factors studied. The coefficient of variation $(\mathrm{CV}=\alpha \mathrm{x}$, where $\mathrm{x}$ is the mean) was presented to indicate the degree of dispersion of the values around the mean. A Principal Component Analysis (PCA) was carried out to see the correlation between the types of substrates used and the yield of sorghum and groundnut.

\section{Results}

\subsection{Physico-chemical characteristics of the different substrates used}

Chi2 tests of $\mathrm{N}$, total $\mathrm{C}$, organic matter and $\mathrm{C} / \mathrm{N}$ ratio, organic matter, exchangeable bases and soil texture show that the difference is not significant at any sampling distance (Table 2).

Table 2: Chi-square test of the physico-chemical properties of different substrates according to sampling distance

\begin{tabular}{|l|l|l|l|l|}
\hline \multirow{2}{*}{ Variables } & \multicolumn{2}{l|}{ Substrate removal distance from cashew nut trunk } & \multirow{2}{*}{ p-value } \\
\cline { 2 - 4 } & $\mathrm{R} / 2$ & $\mathrm{R}$ & $2 \mathrm{R}$ & \\
\hline pHeau (1/2,5) & 5,16 & 4,94 & 4,88 & 0,995 \\
\hline P assimilable (ppm) & 11,590 & 13,307 & 18,029 & 0,459 \\
\hline C total (\%) & 0,495 & 0,353 & 0,358 & 0,984 \\
\hline $\mathrm{N}$ total (\%) & 0,056 & 0,049 & 0,031 & 0,996 \\
\hline $\mathrm{MO}(\%)$ & 0,85 & 0,61 & 0,62 & 0,973 \\
\hline $\mathrm{C} / \mathrm{N}$ & 8,91 & 7,16 & 11,44 & 0,603 \\
\hline $\mathrm{Ca}{ }^{2+}(\mathrm{méq} / 100 \mathrm{~g})$ & 1,911 & 2,119 & 1,578 & 0,960 \\
\hline Mg ${ }^{2+}(\mathrm{méq} / 100 \mathrm{~g})$ & 0,238 & 0,201 & 0,119 & 0,980 \\
\hline $\mathrm{K}^{+}(\mathrm{méq} / 100 \mathrm{~g})$ & 0,093 & 0,097 & 0,071 & 0,997 \\
\hline Clay (\%) & 6,78 & 7,97 & 8,61 & 0,895 \\
\hline Limon (\%) & 4,21 & 4,31 & 4,27 & 0,999 \\
\hline Sand (\%) & 89,02 & 87,73 & 87,12 & 0,989 \\
\hline
\end{tabular}


Vol. 5, No. 01; 2020

ISSN: $2456-8643$

\subsection{Influence of cashew nut substrate on sorghum growth}

The yield of sorghum on different substrates was studied according to biomass growth and production.

\subsubsection{Sorghum height growth according to different substrates}

Analysis of variance on sorghum height growth shows a significant difference $(\mathrm{p}=0.0202)$. Thus the height in $\mathrm{R} / 2$ increases from $9.88 \mathrm{~mm}$ at $\mathrm{T} 1$ to $116.6 \mathrm{~mm}$ at $\mathrm{T} 6$. On the R substrate, it increases from $9.66 \mathrm{~mm}$ in $\mathrm{T} 1$ to $80.36 \mathrm{~mm}$ in T6. Finally, for 2R, it increases from $10 \mathrm{~mm}$ in $\mathrm{T} 1$ to $86.19 \mathrm{~mm}$ (Figure 4).

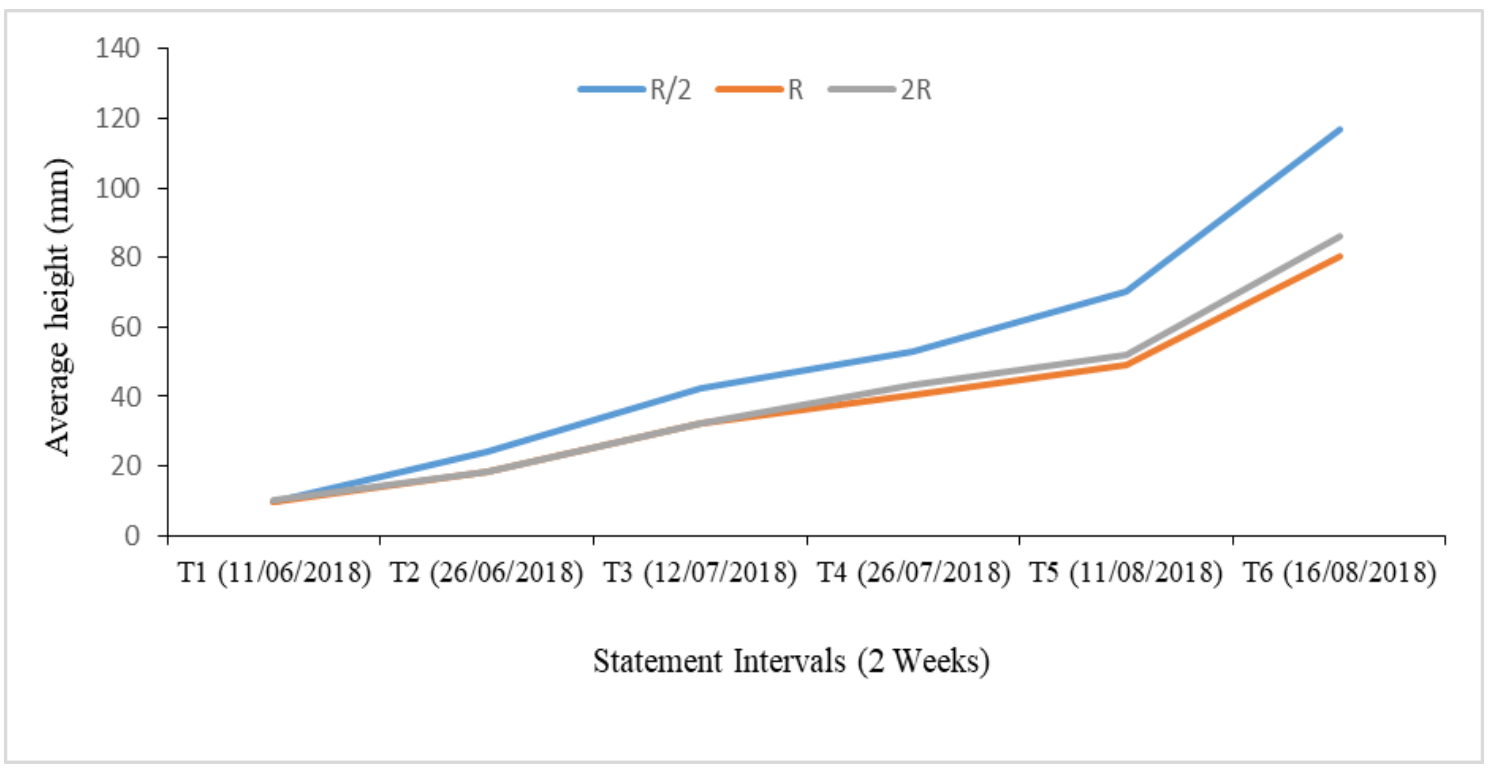

Figure 4: Sorghum height growth on different substrates as a function of time

\subsubsection{Diameter growth at the sorghum collar}

Comparison of the averages of diameter at the collar does not show a significant difference $(\mathrm{p}=$ $0.55)$. On the other hand, on the $\mathrm{R} / 2$ substrate a mean diameter equal to $12.17 \mathrm{~mm}$ is noted as opposed to $10.1 \mathrm{~mm}$ in $\mathrm{R}$ and $9.69 \mathrm{~mm}$ in $2 \mathrm{R}$ (Figure 5).

However, the analysis of variance shows a significant difference $(\mathrm{P}<0.05)$ in mean diameter between dates T2, T3, T4 and T5 except T1 and T6 (Table 3). 


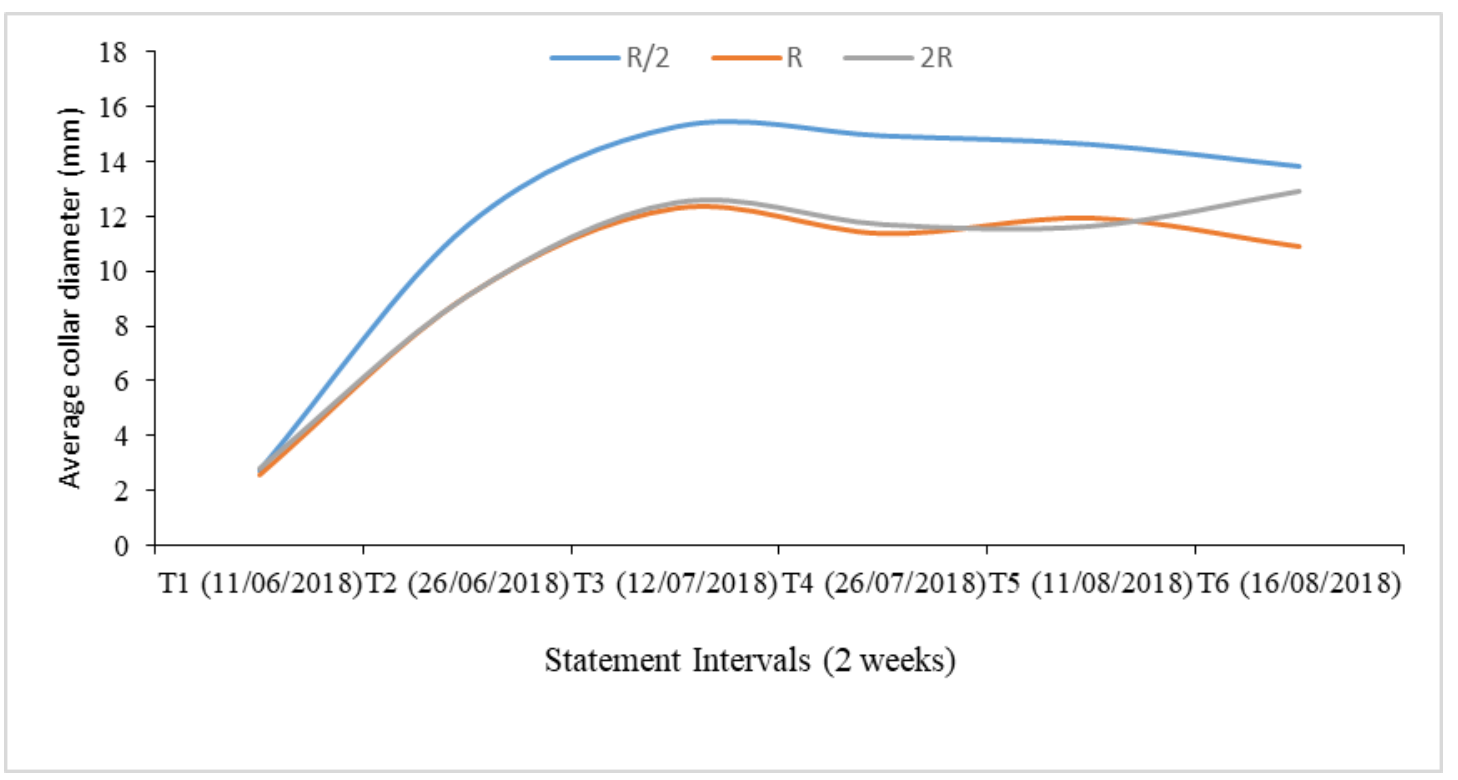

Figure 5: Average collar diameter on different substrates

Table 3: Analysis of variance of sorghum collar diameter by sampling distance

\begin{tabular}{|c|c|c|c|c|c|}
\hline Variables & Df & $\begin{array}{l}\text { Sum of } \\
\text { Squares }\end{array}$ & $\begin{array}{l}\text { Average of } \\
\text { Squares }\end{array}$ & F-value & $\operatorname{Pr}(>\mathbf{F})$ \\
\hline Dmc en $\mathrm{T} 1$ & 2 & 0,36 & 0,358 & 0,019 & $0,893^{\mathrm{ns}}$ \\
\hline Dmc en $\mathrm{T} 2$ & 2 & 84,26 & 84,26 & 6,609 & $0,0213 *$ \\
\hline Dmc en T3 & 2 & 96,25 & 96,25 & 8,139 & $0,0136 *$ \\
\hline Dmc en $\mathrm{T} 4$ & 2 & 112,1 & 112,07 & 10,56 & $0,00633 * *$ \\
\hline Dmc en T5 & 2 & 133 & 133 & 14,78 & $0,00203 * *$ \\
\hline Dmc en $\mathrm{T} 6$ & 2 & 4,36 & 4,356 & 0,231 & $0,639^{\mathrm{ns}}$ \\
\hline \multicolumn{6}{|c|}{ Legend : Dmc $=$ Average diameter at collar } \\
\hline \multicolumn{6}{|c|}{ Meaning codes: 0 ‘***’,0.001 ‘**,0.01 ‘*,0.05 ‘,0.1 ‘, 1} \\
\hline
\end{tabular}

\subsubsection{Effect of cashew nut substrate on sorghum biomass production}

Analysis of variance shows significant differences in above-ground biomass $(p=0.00129)$, root biomass $(\mathrm{p}=0.014)$ and total biomass $(\mathrm{p}=0.00129)$. Thus, for the above-ground biomass, the median values of $R / 2, R$ and $2 R$ vary respectively 215; 112 and 117 (Figure 6a). For root 
biomass, they vary from 37 for $\mathrm{R} / 2,21$ for $\mathrm{R}$ and 21 for $2 \mathrm{R}$ (Figure 6b). Finally, for total biomass, they vary from 252 for $\mathrm{R} / 2,135$ for $\mathrm{R}$ and 138 for $2 \mathrm{R}$ (Figure $6 \mathrm{c}$ ).

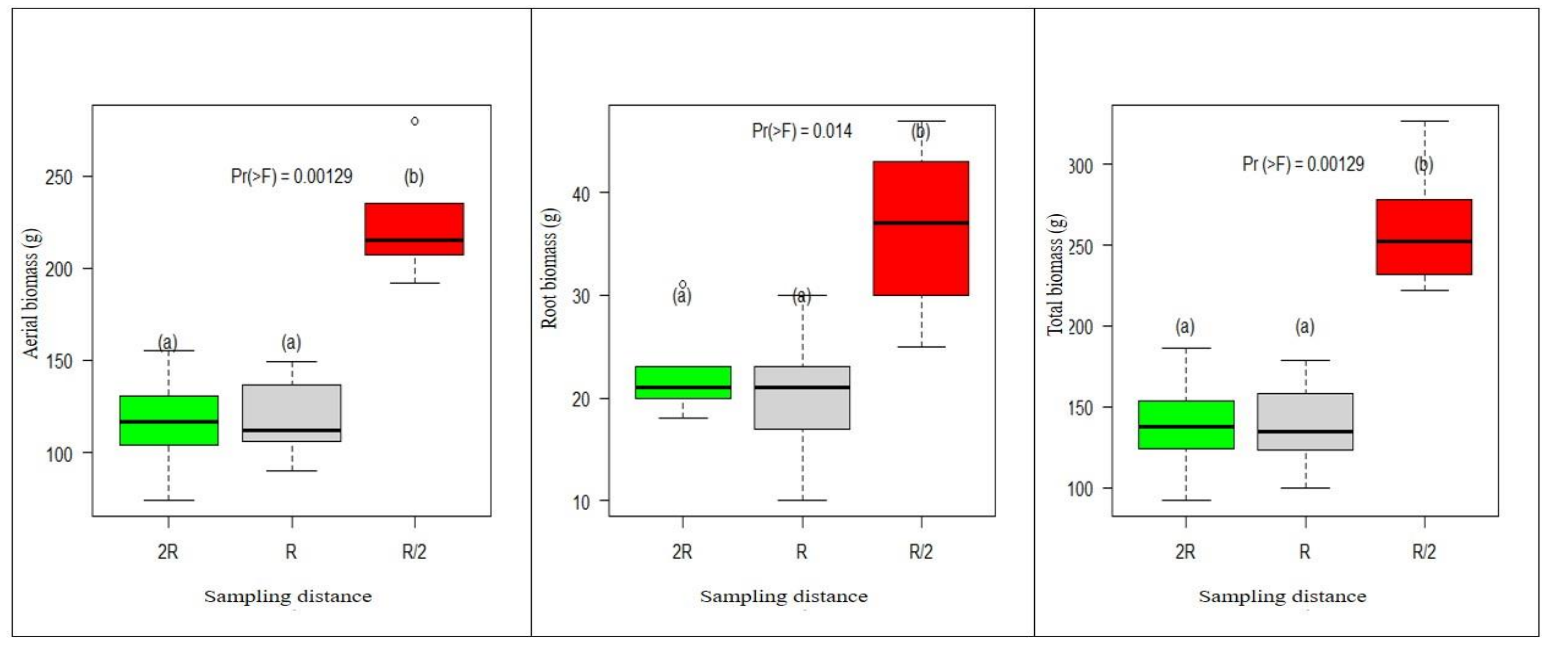

Figure 6: Evaluation of the above-ground (A), root (B) and total (C) biomass of sorghum according to sampling distance

\subsection{Influence of cashew nut substrate on peanut growth}

\subsubsection{Dynamics of peanut leaf growth by substrate type}

Figure 8 shows the dynamics of growth, including the number of branches of the peanut as a function of time following the sampling distance $(R / 2, R$ and $2 R)$. The $R / 2$ substrate favoured more branching with an average of $33.13 \pm 7.49$ branches followed by $\mathrm{R}$ with $31.18 \pm 6.74$ branches and $2 \mathrm{R}$ with $26.27 \pm 7.83$ branches. However, the mean comparison test showed no significant difference between the different types of substrates $(\mathrm{p}=0.898)$.

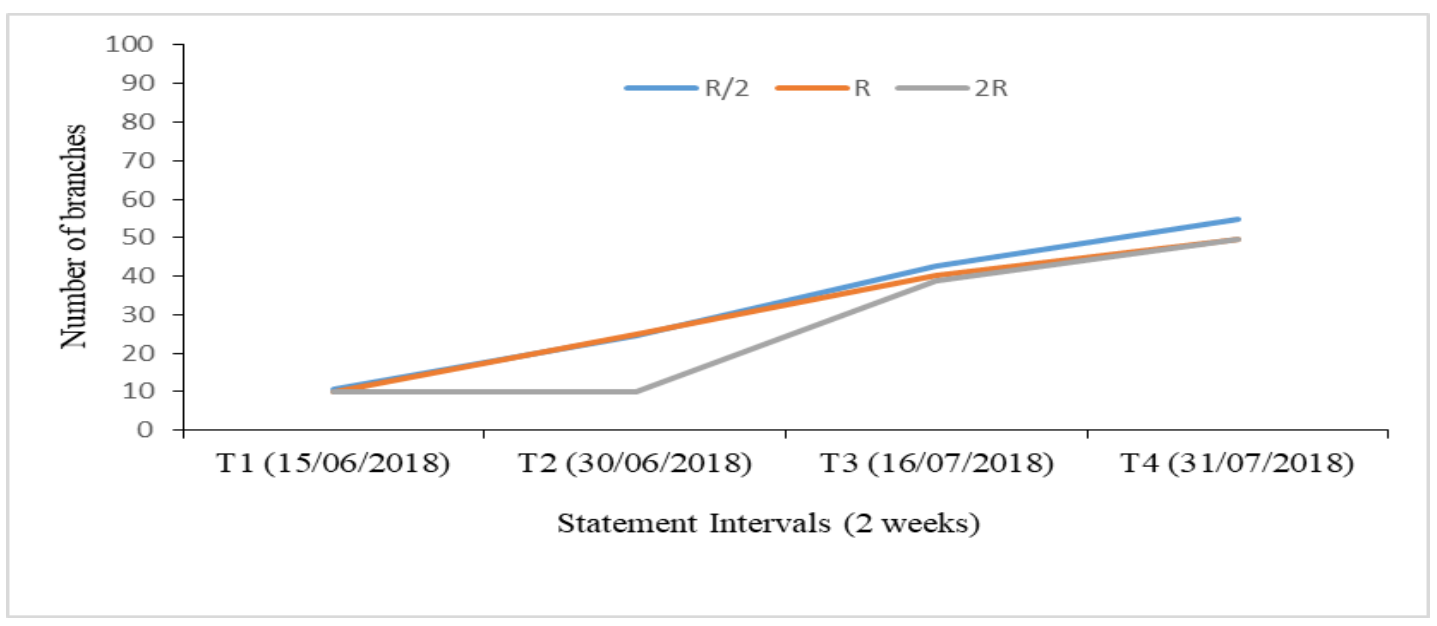

Figure 8: Dynamics of peanut leaf branching as a function of time following sampling distance 


\subsubsection{Influence of Soil Sampling Distance on Peanut Yield}

The test comparing the averages of pod production over sampling distances (Figure 9a) shows a significant difference $(\mathrm{p}=0.0388)$. Pod production is significantly higher at $\mathrm{R} / 2$ and $\mathrm{R}$ substrates with $230.2 \pm 15.2 \mathrm{~g}$ and $230 \pm 8.6 \mathrm{~g}$ respectively compared to $2 \mathrm{R}$ with $189.4 \pm 25.9 \mathrm{~g}$. On the other hand, the comparison of averages in mature pods (Figure 9b) shows no significant difference $(\mathrm{p}=0.425)$ even though the highest average is recorded on $\mathrm{R} / 2(209 \pm 15 \mathrm{~g})$ compared to $203 \pm 5.8 \mathrm{~g}$ in $\mathrm{R}$ and $163.8 \pm 23.9 \mathrm{~g}$ in $2 \mathrm{R}$. No significant differences were noted in the total biomass/pod production ratio $(\mathrm{p}=0.169)$ and the total biomass/ mature seed ratio $(\mathrm{p}=0.503)$. However, on R/2 and R, the ratios are 3.270 and 3.022 respectively, compared to 2.794 on $\mathrm{R}$ (Figure 9c). The ratio of biomass to mature seed gives almost the same values regardless of the sampling distance (Figure 9d).

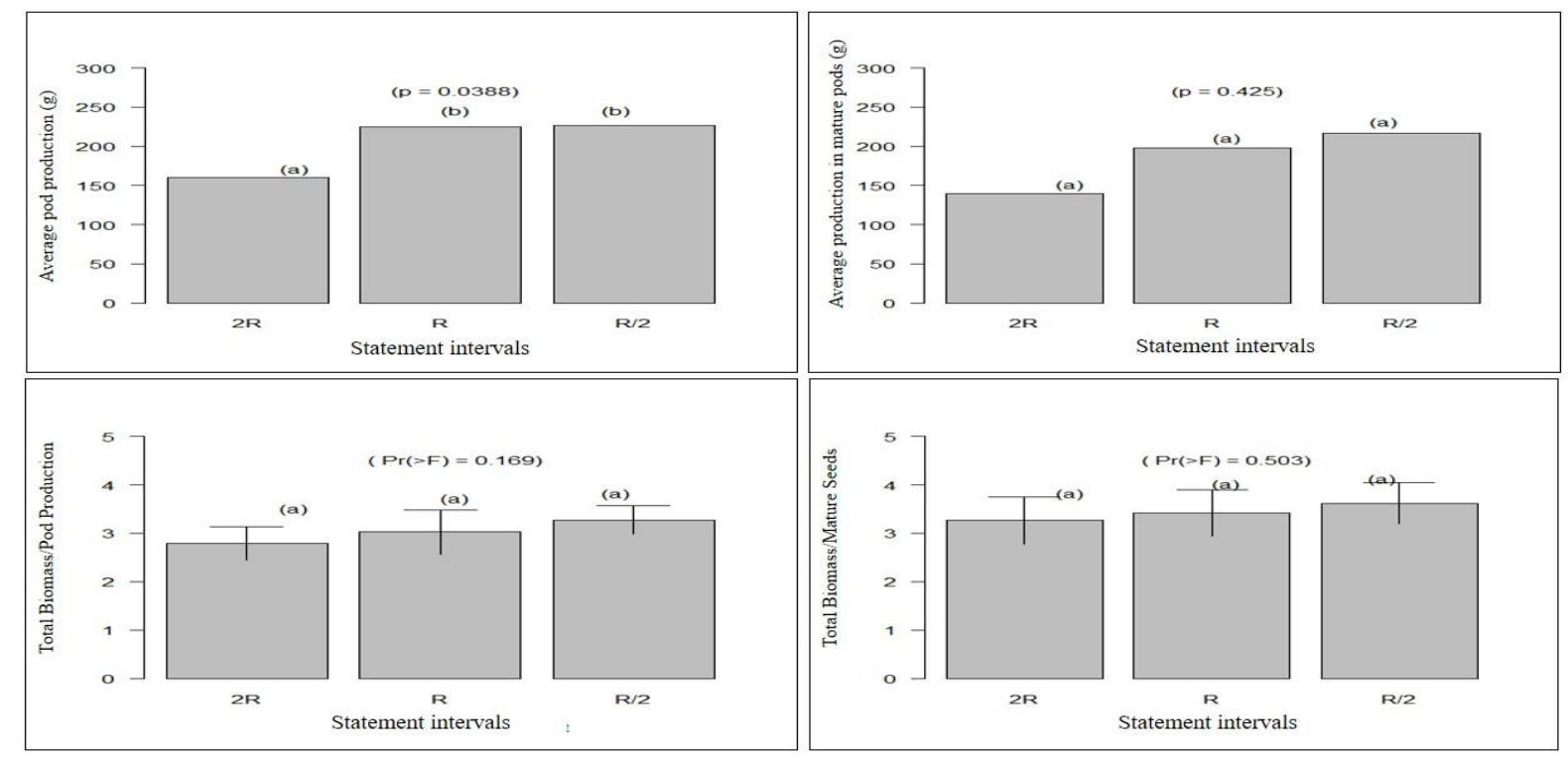

Figure 9: Effect of crop soil sampling distance on pod production (a), mature pod production (b), total biomass/pod production ratio (c) and total biomass/mature pod production ratio (d)

\subsubsection{Effect of sampling distance on peanut biomass production}

An analysis of variance shows that the above-ground biomass is higher on the $R / 2$ substrate with a significant difference between the different substrates $(\mathrm{p}=8.58 \mathrm{e}-05)$, the root biomass is high on the R substrate without significant difference $(\mathrm{p}=0.355)$ and the total biomass is higher on the $\mathrm{R}(331 \mathrm{~g})$ and $\mathrm{R} / 2$ (294 $\mathrm{g}$ ) substrates compared to $2 \mathrm{R}$ (257 g). However, the difference is significant $(\mathrm{p}=0.0129)$. (Figure 10). 


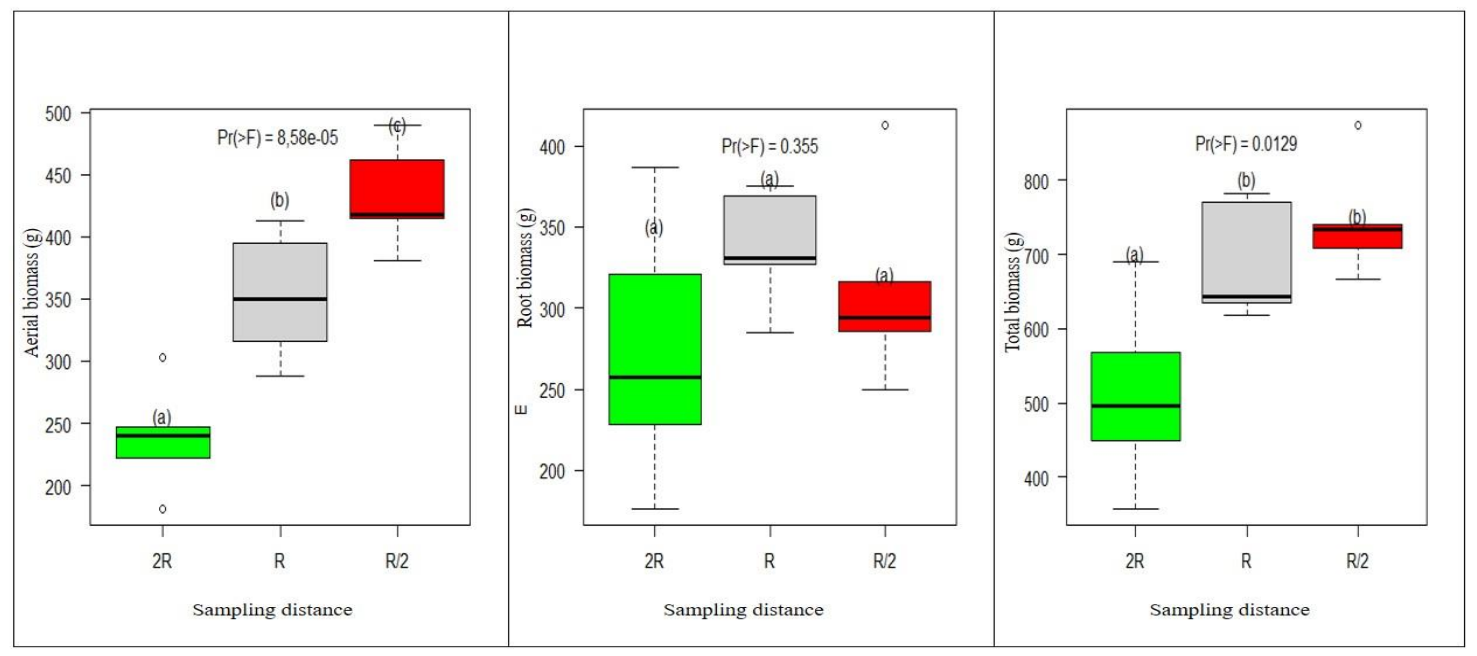

Figure 10: Assessment of aerial (a), root (b) and total (c) biomass of peanuts by sampling distance

\section{DISCUSSION}

Sorghum growth and yield parameters such as height, crown diameter and total biomass were more important on soil collected at R/2 crown. This difference in yield could be explained by the fact that the physico-chemical properties of the substrate used in the experiment showed higher levels of carbon, nitrogen and phosphorus at $R / 2$ than at $R$ and $2 R$. This phenomenon was demonstrated in a bioassay, that the above-ground biomass and height growth of Sorghum vulgare was greater on the substrate collected under the canopy than outside the canopy of A. albida and Ziziphus spina christi [3]. According to these authors, both species improved soil fertility over a distance equivalent to twice the tree crown radius. In addition, Sama-Lang [14] noted in a corridor cropping system that 10 years after planting, tree hedges of Senna spectabilis, Leucaena leucocephala, Calliandra calthyrsus and Gliricidia sepium enriched the corridor soils compared to controls. This association of crops with cashew may have mutual benefits. Previous studies have shown that legumes associated with cashew seedlings also promote cashew growth [2]. Abeysinghe [15] makes the same point in explaining the benefits of combining annual crops with cashew nuts. Studies conducted by Opoku-Ameyaw [16] on the effect of annual crop combination on cashew tree growth and production in Ghana showed that the use of maize and sorghum or groundnut significantly improved tree height and trunk circumference of cashew trees.

The results obtained on groundnut growth and yield showed that the substrate sampled under the cashew nut compared to that sampled outside the cashew nut. Pod production, mature pod production and total biomass were higher on the "R/2" substrate (under cashew nut). This reflects the difference in fertility of these types of substrates used. This result confirms the nature of the physico-chemical properties of the substrates which clearly shows a slight difference in fertility in carbon, nitrogen, organic matter and exchangeable bases essential for crop growth and productivity. Indeed, carbon is important as the main food element for soil organisms. It is an 
Vol. 5, No. 01; 2020

ISSN: $2456-8643$

essential element for the growth of hulls and seeds [17]. A deficiency in this element is therefore manifested by a high rate of empty pods and a brittle shell for groundnut. The results of the experiment showed that empty pods were more noticeable on the $2 \mathrm{R}$ substrate. However, a nitrogen deficiency would result in an early cessation of growth with discoloured leaves. This difference in fertility level could be due to the poor nature of Senegalese agricultural soils. According to Aubert and Duchaufour [18], Senegal's peanut lands belong to the tropical ferruginous soils marked by a deficiency in organic matter, slightly acidic and very low in phosphorus. The cultivation of recently cleared ferralitic soil leads very quickly to a decrease in total nitrogen stock at an annual rate of about $4 \%$. These findings confirm the characteristics of the different types of substrate.

\section{CONCLUSION}

The results of this experiment would indicate that while cashew nuts are an allelopathic species, the substrate under the tree is favourable for the development of annual crops. A field experiment allowing the introduction of other parameters, such as the shade effect, would provide a better understanding of the conditions under which crops are associated with cashew nuts. This would be an alternative in the improvement of crop yields and would also contribute to a better security for producers.

\section{Acknowledgements}

The authors express their gratitude to the Ministry of Higher Education, Research and Innovation of Senegal through the Fonds d'Impulsion pour la Recherche Scientifique et Technique (FIRST 2015) which made this study possible.

\section{REFERENCES}

[1] PADEC (Programme de l'Appui au Développement Economique de la Casamance), «Enquête sur le sous-secteur de l'anacarde au Sénégal ». Résumé global (2016). 23p

[2] Ndiaye S, Charahabil M M, Ndiaye O, Diatta M, «Influence de la flore ligneuse associée dans la production des parcs à Anacardium occidentale L. dans la communauté rurale de Djibanar (Casamance/Sénégal) ». Int. J. Biol. Chem. Sci. 2017. 11(2): 585-596

[3] Ndiaye S A, Faye E, Gueye T, Margolis H, Claud C, «Cordyla pinnata améliore les propriétés du sol et la productivité des cultures ». Ecole Nationale Supérieure d'Agriculture (ENSA) Thiès-Sénégal. Int. J. Biol. Chem. Sci, 6(2): 714-725 2012.

[4] Rice E L, « Allelopathy », Second Edition, Academic Press, 422p, 1984.

[5] Gomez A L., Canham C.D, «Neighbourhood analyses of the allelopathic effects of the invasive tree Ailanthus altissima in temperate forests ». Journal of Ecology 2008. $96: 447-458$

[6] Waller GR, «Allelochemical action of some natural products,. In: Chou $\mathrm{CH}$, Waller Phytochemica/Ecology : Allelochemicals, Mycotoxins and lnsect Pheromones and Allomones ». Academia Sinica Monograph Series, n 9. Taipei: Institute of Botany, 129-54, 1989. 
[7] Siqueira JO, Nair MG, Hammerschmidt R, Safir GR, « Significance of phenolic compounds in plant-soil-microbial systems ». Crit Rev Plant Sei, 10: 63-121, 1991.

[8] Samb C.O, Faye E, Dieng M, Sanogo D, Samba NSA et Koita B, « Dynamique spatiotemporelle des plantations d'anacardier (Anacardium occidentale L.) dans deux zones agroécologiques du Sénégal ». Afrique SCIENCE 14(3) 365 - 377, 2018.

[9] ANSD, «Situation économique et sociale régionale ». Service Régional de la Statistique et de la Démographie de Ziguinchor, 6p, 2013.

[10] Bray RL, Kurtz LT, «Determination of total, organic and available form of phosphorus in soils». Soils Sci., 59: 39-45, 1945.

[11] Bremner JM, Mulvaney CS, «Nitrogen-Total. In Methods of Soils Analysis. Part 2. Chemicals and Microbiological Properties» (2nd edn), Page AL, Miller RH, Keeney DR (eds). Soil Science Society of America, Madison: Wisconsin, 595-624, 1982.

[12] Bruckert S, Andreux F., Correa A, Ambouta K.J.M. et Souchier B. Fractionnement des agrégats appliqués à l'analyse des complexes organo-minéraux des sols. Note technique Centre pédologie'fiologique, no22, 1978.

[13] Feller C, Burtin G, Gerard B, Balesdent J, «Utilisation des résines sodiques et des ultrasons dans le fractionnement granulométrique de la matière organique des sols. Intérêt et limites». Sciences du sol, vol. 29,2 :77-93, 1991.

[14] Sama-Lang P, Nwaga D, Tomekpe K, Bilong P, «Apport des Légumineuses agroforestières pour l'amélioration du rendement des bananiers plantains». Résumés des communications. Réseau de chercheurs en Biotechnologies végétales. Animation scientifique régionale: Biotechnologies et maîtrise des intrants agricoles en Afrique centrale, 17-19 décembre, 2007.

[15] Abeysinghe D. C, «Effect of intercropping of young cashew (Anacardium occidentale L.) on land productivity. In: Recent Developments in Cashew Research ». 23 p Attanayaka, D.P.S.T.G., and Jayasekera, S.J.B.A. (Eds.). Proceedings of the Cashew Research Workshop held on 20 November 2009 at the Faculty of Agriculture and Plantation Management of the Wayamba University of Sri Lanka.

[16] Opoku-Ameyaw K., Oppong F. K., Amoah F. M., Osei-Akoto S. and E. Swatson, «Growth and early yield of cashew intercropped with food crops in northern Ghana». J. Tropical Agri, 49 (1-2): $53-57,2011$

[17] Diallo A, «Effet du stress salin sur la croissance de variétés d'arachide (Arachis hypogea) cultivées au Sénégal». Mémoire de Master. Université Assane Seck de Ziguinchor (Sénégal). 55p, 2016.

[18] Aubert G, «La classification des sols utilisée par les pédologues français en zone tropicale ou aride». SOLS AFRIC IX 1, 97-106, 1956. 